\title{
Ring-testing and Field-validation of a Terrestrial Model Ecosystem (TME) - An Instrument for Testing Potentially Harmful Substances: Effects of Carbendazim on Organic Matter Breakdown and Soil Fauna Feeding Activity
}

\author{
BERNHARD FÖRSTER, ${ }^{1, *}$ CORNELIS A.M. VAN GESTEL,${ }^{2}$ JOSÉE E. KOOLHAAS, ${ }^{2}$ \\ GERRIT NENTWIG, ${ }^{1}$ JOSÉ M.L. RODRIGUES, ${ }^{3}$ J. PAULO SOUSA, ${ }^{4}$ SUSAN E. JONES ${ }^{5}$ AND \\ THOMAS KNACKER ${ }^{1}$ \\ ${ }^{1}$ ECT Oekotoxikologie GmbH, Böttgerstr. 2-14, D-65439 Flörsheim, Germany \\ ${ }^{2}$ Institute of Ecological Science, Vrije Universiteit, De Boelelaan 1085, 1081 HV Amsterdam, The Netherlands \\ ${ }^{3}$ Departamento de Biologia, Universidade de Aveiro, P-3810-193 Aveiro, Portugal \\ ${ }^{4}$ IAV, Instituto Ambiente e Vida, Departamento de Zoologia, Universidade de Coimbra, P-3004-517 Coimbra, \\ Portugal \\ ${ }^{5}$ School of Agricultural and Forestry Sciences, University of Wales, Bangor, Deiniol Road, Bangor, Gwynedd \\ LL57 2UW, United Kingdom
}

Accepted 24 October 2002

\begin{abstract}
Organic matter (OM) decomposition and soil fauna feeding activity were integrated as functional endpoints into ecotoxicological tests with intact-soil-core Terrestrial Model Ecosystems (TMEs). Cellulose filter paper served as standardized OM and was either inserted into the top soil or placed on the soil surface for a period of up to 16 weeks. Faunal feeding activity was assessed by the bait-lamina method. The fungicide carbendazim, applied at six dosages ranging from $0.36 \mathrm{~kg} / \mathrm{ha}$ to $87.5 \mathrm{~kg}$ a.i./ha, served as a model chemical. To validate the results from the TME test, a field study was run in parallel. In TMEs the cellulose paper inserted into the soil was decomposed faster than under field conditions. The carbendaziminduced effects on OM decomposition in TMEs and in the field were comparable and followed a clear doseresponse relationship. The calculated $\mathrm{EC}_{50}$ values after 8 weeks of incubation were $9.5,7.1$ and $2.1 \mathrm{~kg}$ carbendazim/ha for grassland TMEs, grassland field and arable TMEs, respectively. The feeding activity of the soil fauna showed a large variability. The $\mathrm{EC}_{50}$ values for the effect of carbendazim on bait-lamina consumption ranged between 2.0 and $56 \mathrm{~kg}$ a.i./ha. Effects on decomposition were correlated with effects on enchytraeids and earthworms but not with effects on bait-lamina consumption.
\end{abstract}

Keywords: organic matter breakdown; carbendazim; bait-lamina; terrestrial model ecosystem; ecotoxicology

*To whom correspondence should be addressed: Tel.: + 49-6145-956460; Fax: + 49-6145-956499;

E-mail: b-foerster@ect.de

\section{Introduction}

The decomposition of organic matter $(\mathrm{OM})$ is one of the most integrating processes within the soil ecosystem (Swift et al., 1979). During the last four 
decades this process was intensively investigated (e.g. Cadisch and Giller, 1997). It is generally accepted that any adverse effect on this complex process might influence nutrient cycling and, in the long run, soil fertility (Eijsackers and Zehnder, 1990). Consequently, effects on OM breakdown represent a valuable endpoint within the environmental risk assessment of chemicals.

While many investigations on the effects of chemicals on OM decomposition took place under field conditions (e.g. Schönborn and Dumpert; 1990, Paulus et al., 1999; Bjørnlund et al., 2000; Cortet and Poinsot-Balaguer, 2000), laboratory microcosms have been used to assess decomposition under more controlled conditions (e.g. Bengtsson et al., 1988; Van Wensem, 1989; Förster et al., 1996; Salminen and Haimi, 1997; Vink and Van Straalen, 1999; Chen and Edwards, 2001). These microcosms were usually composed of homogenized soil and litter and selected soil animals were added. Sowerby et al. (2000) used small intact soil core microcosms with autochthonous soil organisms to assess litter decomposition under conditions more related to field situations. However, no field-validation of the decomposition data from microcosms has been described so far.

Our objective was to integrate the decomposition of $\mathrm{OM}$ as a non-destructive endpoint into tests with Terrestrial Model Ecosystems (TME) and to compare the data gained under these controlled conditions with data from a field-validation study run in parallel. From the various methods to assess OM decomposition that are described in the scientific literature (e.g. Knacker et al., 2004), two were chosen for this project. Firstly, cellulose paper seemed to be a suitable standardized and homogeneous organic material (Bienkowski, 1990) to be applied in the TME test. Cellulose paper can be exposed in small amounts without being encased since, on retrieval, remnants of the cellulose paper can easily be distinguished from native organic matter and soil. Secondly, the bait-lamina method, first introduced by Von Törne (1990a, b) as a tool to measure the feeding activity of the soil community, was applied. This method has been proposed as a screen to determine the effects of pesticides, both under laboratory conditions in micro- and mesocosms and in field studies (Larink, 1994a, b; Larink and Kratz, 1994; Kratz, 1998; Kula and Römbke, 1998).
The study was part of a research project sponsored by the European Union (EU) entitled "The use of Terrestrial Model Ecosystems (TME) to assess environmental risks in ecosystems" (Contract No.: ENV4-CT97-0470) in which four partners (1) ECT Oekotoxikologie $\mathrm{GmbH}$ in Floersheim (Germany), (2) Vrije Universiteit Amsterdam (Institute of Ecological Science, The Netherlands), (3) University of Wales in Bangor (School of Agricultural and Forestry Sciences, UK) and (4) Universidade de Coimbra (Instituto Ambiente e Vida, Portugal) ring-tested and field-validated the TME system (Knacker et al., 2004).

\section{Materials and methods}

During the first year of the study a TME pre-test was conducted to gain experience with the TME equipment and the methods used for measuring the OM breakdown and the feeding activity of the soil organisms. In the second year, based on the experience of the previous year, the study design for the TME ring-test and field-validation study was specified and both parts of the project were performed simultaneously.

\section{Field sites}

The field site of Partner 1 (Flörsheim) was located in an agricultural region near the city of Frankfurt am Main, Germany. The selected grassland (silty clay loam; $\mathrm{pH}$ 5.3-5.9) is exposed to an annual average precipitation of $650 \mathrm{~mm}$. The field site of Partner 2 (Amsterdam) is situated in an agricultural region in The Netherlands. It is also grassland with an average annual rainfall of $790 \mathrm{~mm}$; the soil is a sandy loam $(\mathrm{pH} \mathrm{4.8-5.1).}$ The field site of Partner 3 (Bangor) is part of a narrow gently undulating glacial drift in North Wales, UK which is used for silage, sheep and cattle grazing. The average annual precipitation is lightly above $1000 \mathrm{~mm}$; the $\mathrm{pH}$ of the loamy soil is 5.8-6.6. The arable land of Partner 4 (Coimbra) is situated in the Modego Valley near Coimbra in Portugal. The average rainfall is approximately $985 \mathrm{~mm}$; the soil is a silty loam (pH 6.4-7.1). 


\section{Terrestrial model ecosystems (TMEs)}

TMEs are defined as controlled, reproducible systems that attempt to simulate the processes and interactions of components in a portion of the terrestrial environment (Gillett and Witt, 1980; Sheppard, 1997). A TME consists of a high density polyethylene tube (length $40 \mathrm{~cm} ; 17.5 \mathrm{~cm}$ in diameter), a high density polyethylene bottom plate, a thin layer of inert gauze to fit between the drilled holes of the bottom plate and the bottom of the soil core, and polyvinyl chloride tubing to connect the bottom plate to a $1000 \mathrm{ml}$ wide neck polyethylene bottle to collect leachate. Intact soil cores were extracted in spring from the respective field sites, transported to the laboratories (Flörsheim, Amsterdam, Coimbra) or greenhouse (Bangor) and placed into (movable) temperature controlled carts.

During the TME pre-test and TME ring-test under laboratory conditions, air temperature ranged between 18 and $26^{\circ} \mathrm{C}$, soil temperature between 10 and $14^{\circ} \mathrm{C}$, relative air humidity between $50 \%$ and $80 \%$. The day/night period was set to $16 /$ $8 \mathrm{~h}$ and the illumination to 8,000-12,000 lux. TMEs were irrigated with artificial rain water modified after Velthorst (1993) up to three times per week. To maintain the soil moist (at least 20\%) each partner had to find out the amount of rainwater required for the specific soil.

\section{Model chemical and test design}

The commercial formulation Derosal containing the systemic fungicide carbendazim (methyl-ben zimidazole-2-ylcarbamate) as active ingredient $(360 \mathrm{~g} / \mathrm{l})$ was chosen as model chemical. To conduct the TME pre-test, four treatment levels (T1$\mathrm{T} 4)$ and the control (T0) were chosen. The highest recommended application rate for Derosal $(11$ / ha), which corresponded to $0.36 \mathrm{~kg}$ carbendazim/ ha, was used for treatment level T1. The spacing factor between treatment levels was six. Based on the results of the pre-test, in the TME ring-test and field-validation study six treatment levels (T1-T6) and the control (T0) were used. The spacing factor between treatment levels was three, resulting in the 243-fold recommended application rate for treatment level T6. Appropriate amounts of Derosal were diluted in demineralised water and a total volume of $50 \mathrm{ml}$ solution was applied in evenly distributed drops directly onto the soil surface of the TME using a pipette. Immediately thereafter each TME was irrigated with $150 \mathrm{ml}$ of artificial rain water.

The design for the field-validation study was identical to that of the TME ring-test. In the field, 30 plots separated by $2 \mathrm{~m}$ of space and each sized $5 \mathrm{~m}$ by $5 \mathrm{~m}$ were installed ( 6 control plots and 4 plots per treatment level, randomized). In the fieldvalidation study, a plot sprayer equipped with ten flat ray spray nozzles, commonly used in agricultural practice (Parzellenspritze PL1, Fa. Baumann, D-74638 Waldenburg, Germany) was employed

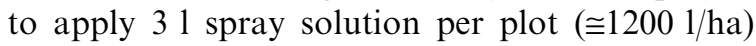
containing the appropriate amount of the model chemical; for the highest treatment level 61 spray solution was used. Immediately thereafter each plot was irrigated with approximately 251 water by using a portable sprayer to rinse any Derosal from the vegetation.

Further details concerning the field sites, the TMEs and the test design are described in Knacker et al. (2004).

\section{Organic matter breakdown}

OM breakdown was determined during the TME ring-test and field-validation test by Partner 1 (Flörsheim) in grassland TMEs and in the field, and by Partner 4 (Coimbra) in arable TMEs. Cellulose filter paper was used as organic material (folded filter paper for quantitative analysis, diameter $70 \mathrm{~mm}$, ash-free, cellulose content $>95 \%$, Co. Schleicher and Schuell, type 595 $1 / 2$ ). Prior to exposure in TMEs and in the field the cellulose paper was immersed in carbendazim-solutions related to the six different treatments. The uptake of carbendazim-solutions by the cellulose paper used by Partner 4 (Coimbra) was equivalent to the respective amounts of carbendazim that would remain on the filter paper if the chemical was applied onto the surface of the unfolded cellulose filter paper. The concentration of the cellulose paper of Partner 1 (Flörsheim) was ten times lower.

Partner 1 (Flörsheim) inserted one folded filter paper per TME vertically (tip down) into the upper soil layer $(0-3.5 \mathrm{~cm})$ and one folded filter paper was placed horizontally on the soil surface. In the field, eight filters per plot were inserted into 
the soil and one unfolded filter disc was exposed on the soil surface. Partner 4 (Coimbra) exposed unfolded cellulose paper horizontally on the soil surface of TMEs. Flörsheim sampled the inserted filter after 8 weeks (two filter papers per plot) and after 16 weeks (six filter papers per plot) while the surface filter was sampled only after 16 weeks; Coimbra sampled the surface filter after 12 weeks.

At sampling time points, the remaining filter paper was carefully removed from the soil by forceps, dried at $105^{\circ} \mathrm{C}$ overnight and weighed. To correct the data for mineral contamination the amount of ash (resulting from contamination of the filter with soil particles) was determined by dry combustion at $550{ }^{\circ} \mathrm{C}$ for $4-5 \mathrm{~h}$. The decomposition was calculated from the weight loss based on the ash-free dry weight of the remaining filter paper material as a percentage of the initial ash-free dry weight (Beyer et al., 1992).

\section{Soil fauna feeding activity}

The feeding activity of the soil fauna was determined at several time intervals after carbendazim treatment, by all partners in TMEs and in the field by applying the bait-lamina method (Kratz, 1998). The bait lamina consisted of perforated PVCsticks with a length of $16 \mathrm{~cm}$. The perforation was filled with a cellulose-based substrate $(70 \%$ cellulose, $29 \%$ wheat bran, $1 \%$ activated carbon). Per TME and field plot four bait-lamina sticks were inserted into the soil. After an exposure period of 2 weeks, decomposition of the substrate was evaluated by counting the number of empty holes. The TME pre-test had been used to determine the appropriate time period for the exposure of the bait-lamina sticks.

\section{Statistical evaluation of data}

Spearman correlations were used to assess the relationship between the effects on decomposition and on soil fauna (Moser et al., 2004a) using the SPSS 7.5 software package. EC $_{50}$ values for the effect of carbendazim treatment on decomposition were calculated by applying the probit analysis (SPSS 7.5). $\mathrm{EC}_{10}$ and $\mathrm{EC}_{50}$ values for the effect of carbendazim treatment on bait-lamina consumption were calculated using a logistic model according to Haanstra et al. (1985). Differences between tests (TME pre-test, TME ring-test and field-validation study) and between sampling times were tested for significance by ANOVA, and $\mathrm{EC}_{50}$ values for different tests were compared applying a Generalized Likelihood Ratio test (Sokal and Rohlf, 1969). Correlation between bait-lamina feeding rate and soil invertebrate density was determined by regression analysis. All these tests were run using the SYSTAT 7.0 software package. NOEC values were determined applying Williams' test or the non-parametric Kruskall-Wallis test in the TOXSTAT software package (Gulley et al., 1991).

\section{Results}

\section{Organic matter breakdown}

Cellulose filter paper was decomposed in the TMEs and in the field, with reduced weight loss if exposed on the soil surface compared to exposure in the top soil (Table 1). Despite the homogeneity of the cellulose paper, the variation between the replicate samples was high, especially for the

Table 1. Weight loss of cellulose paper either inserted into the soil or placed on the soil surface for periods of 8 and 16 weeks in control grassland TMEs and control field plots, and 12 weeks in control arable TMEs

\begin{tabular}{|c|c|c|c|c|c|}
\hline \multirow{2}{*}{$\begin{array}{l}\text { Exposure time of } \\
\text { cellulose paper }\end{array}$} & \multicolumn{4}{|c|}{ Grassland (Flörsheim) } & \multirow{2}{*}{$\begin{array}{l}\text { Arable (Coimbra) } \\
\text { TME (12 week) }\end{array}$} \\
\hline & TME (8 week) & Field (8 week) & TME (16 week) & Field (16 week) & \\
\hline $\begin{array}{l}\text { On the soil } \\
\text { surface }\end{array}$ & $47.9 \pm 41.4$ & n.d. & $64.4 \pm 40.7$ & $72.7 \pm 30.9$ & $27.7 \pm 7.9$ \\
\hline $\begin{array}{l}\text { Inserted into } \\
\text { the soil }\end{array}$ & $95.1 \pm 11.8$ & $50.4 \pm 18.5$ & $100 \pm 0.0$ & $95.2 \pm 7.2$ & n.d. \\
\hline
\end{tabular}

n.d. = not determined.

Mean values and standard deviations are given in percent of the initial weight of the cellulose paper $(n=6)$. 
grassland soil. After 8 weeks, weight loss was most pronounced in the grassland TMEs and when the filter paper was inserted in the soil. On average $95.1 \%$ of the initial weight was decomposed in the control TMEs and $50.4 \%$ in the field control plots. If exposed on the soil surface of grassland TMEs, $47.9 \%$ of the initial weight was lost in the controls within 8 weeks, whereas in TMEs with arable soil only $27.7 \%$ had been decomposed after 12 weeks. In the untreated controls of the grassland TMEs and the respective field-validation study, 95-100\% of the cellulose was decomposed after 16 weeks when inserted into the soil; when placed on the soil surface, on average $64.4 \%$ (TME) and $72.7 \%$ (field) of the cellulose paper was decomposed (Table 1).

Increasing application rates of carbendazim caused decreasing decomposition rates of the cellulose paper as compared to the respective untreated controls in grassland TMEs and field plots (Fig. 1) and in arable TMEs (Fig. 2). The effects were most pronounced in the arable TMEs of Coimbra. The effects of carbendazim on OM decomposition were positively correlated with the

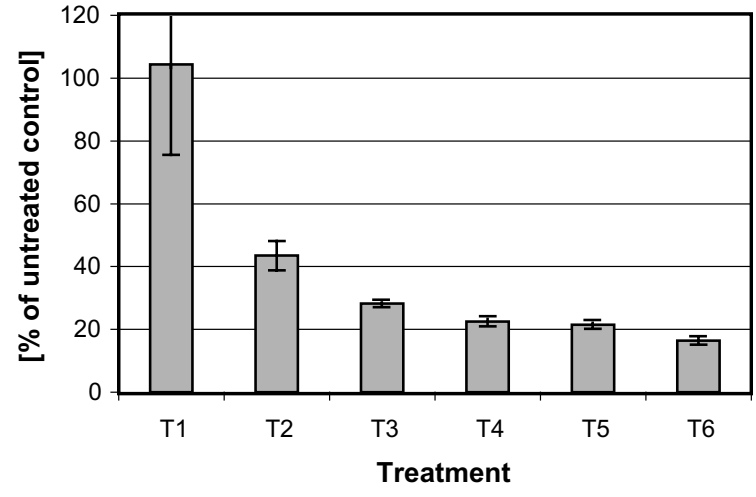

Figure 2. Effect of carbendazim treatment on the weight loss of cellulose filter paper placed on the soil surface of arable TMEs for 12 weeks. See Fig. 1 for further explanation.

effects on abundance of Enchytraeidae in TMEs and in the field plots (Table 2). When relating decomposition of cellulose paper exposed for 8 weeks in grassland TMEs either inserted into the soil or placed on the soil surface to the number of enchytraeids, $R^{2}$ was 0.943 and 0.979 , respectively. Such a good correlation with effects on

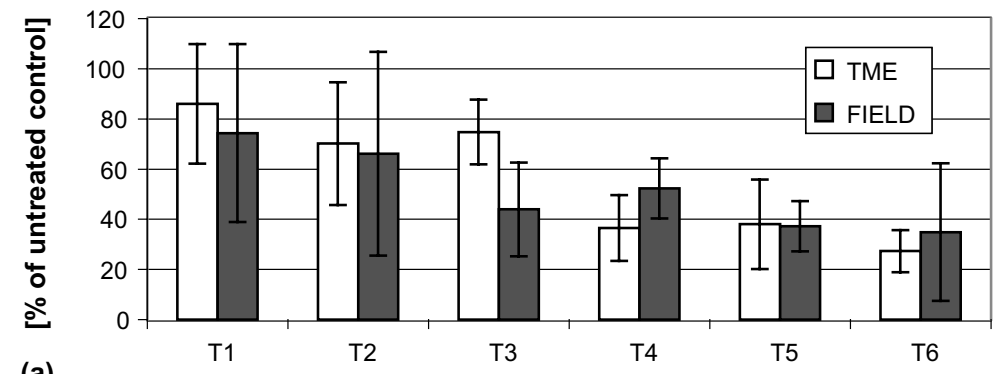

(a)

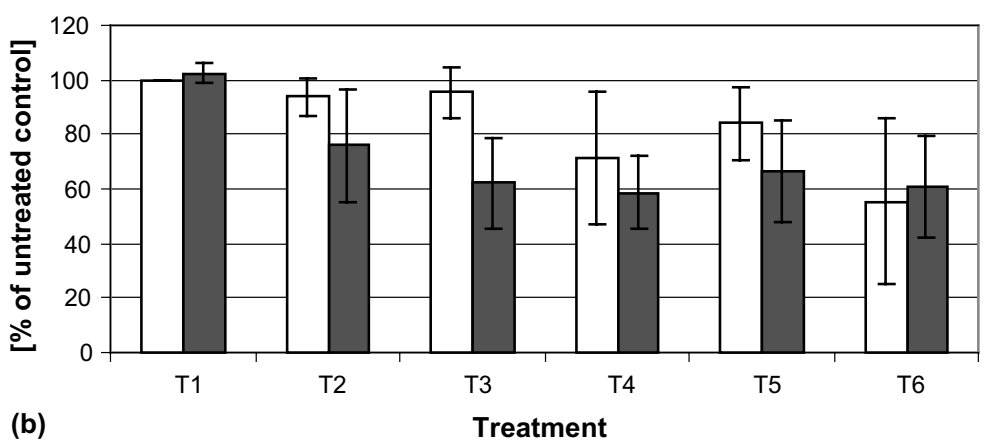

Figure 1. Effect of carbendazim treatment (T1-T6 refer to increasing treatment rates; see text) on weight loss of cellulose filter paper inserted into the top soil of grassland TMEs and in the field of Flörsheim and incubated for 8 weeks (a) or 16 weeks (b). Given are the mean and standard deviation $(n=4)$ of weight losses at each treatment level compared to the untreated control. 
Table 2. Correlations between decomposition of cellulose paper and the abundance of Enchytraeidae and biomass of earthworms in grassland TMEs and field plots at 8 and 16 weeks after application of the model chemical carbendazim

\begin{tabular}{|c|c|c|c|c|c|}
\hline & \multirow[b]{2}{*}{ Weeks } & \multicolumn{2}{|c|}{ Cellulose inserted into soil } & \multicolumn{2}{|c|}{ Cellulose on soil surface } \\
\hline & & TME & Field & TME & Field \\
\hline \multirow{2}{*}{$\begin{array}{l}\text { Abundance of } \\
\text { Enchytraeidae }\end{array}$} & 8 & $0.943^{* *}$ & $0.829^{*}$ & $0.979 * *$ & n.d. \\
\hline & 16 & n.s. & $0.870^{*}$ & n.s. & n.s. \\
\hline \multirow{2}{*}{$\begin{array}{l}\text { Biomass of } \\
\text { earthworms }\end{array}$} & 8 & n.s. & n.d. & $0.829 *$ & n.d. \\
\hline & 16 & $0.886^{*}$ & n.s. & n.s. & n.s. \\
\hline
\end{tabular}

n.d. $=$ not determined; n.s. $=$ not significant; $*$ significant at $p=0.05 ; * *$ significant at $p=0.01$.

Given are $R^{2}$ values.

enchytraeids was also found for decomposition of cellulose paper inserted into the soil in the field, but not with decomposition of cellulose incubated on top of the soil (Table 2). A significant correlation was also found between the effects of carbendazim on biomass of earthworms and decomposi-tion of cellulose paper inserted into the soil of grassland TME after 16 weeks $\left(R^{2}=\right.$ 0.886). For detailed data on the effects on Enchytraeidae and earthworms, see Moser et al. (2004).

The $\mathrm{EC}_{50}$ values calculated for the effect of carbendazim on cellulose paper decomposition in the soil after 8 weeks of incubation ranged from $9.5 \mathrm{~kg}$ a.i./ha for the grassland TMEs to $7.1 \mathrm{~kg}$ a.i./ha for the grassland field-validation study. The respective $\mathrm{EC}_{50}$ value for the effect on cellulose paper decomposition exposed on the soil surface of the arable TMEs was 2.1 a.i. $\mathrm{kg} / \mathrm{ha}$. No $\mathrm{EC}_{50}$ could be calculated for the effects after 16 weeks of exposure in TMEs and in the field since the data did not follow a clear dose response relationship.

\section{Bait lamina feeding rate}

All tests, except those performed in Coimbra, revealed a reduction of bait-lamina feeding activity at high carbendazim dosages. Fig. 3 shows the response of bait-lamina consumption in the TME ring-test after 8 and 16 weeks. Similar responses were observed in the TME pre-test and the fieldvalidation study (data not shown). Substrate consumption rates, measured as the percentage of open holes in the bail-lamina sticks after 2 weeks of incubation, showed significant differences between the different sampling times and also between the different sites. Results of TME pre-test and TME ring-test did not differ and results of TME ring-test and field-validation study were only significantly different in Amsterdam and Coimbra (ANOVA; $p<0.05$ ). In the controls of the TME pre-test, average substrate consumption was $29.2-$ $32.2 \%, 25.5-64.3 \%, 21.9-69.8 \%$ and $15.6-34.1 \%$ in the Amsterdam, Bangor, Coimbra and Flörsheim soils, respectively. For the TME ring-test these control consumption values were 59.6-76.6\%, $44.9-57.0 \%, 39.8-71.9 \%$ and $37.2 \%$, respectively, and for the field-validation study control consumption was $27.9-43.2 \%, 37.5-47.1 \%, 55.2-$ $85.9 \%$ and $24.0 \%$, respectively, after 14 days of bait-lamina sticks incubation.

Bait-lamina consumption was related to soil moisture content. Highest correlation with soil moisture content was found in Bangor $(0.375<$ $R^{2}<0.401$ for TME pre-test, TME ring-test and field-validation study) followed by Coimbra (0.288 $\left.<R^{2}<0.329\right)$, Flörsheim $\left(0.257<R^{2}<0.276\right)$ and Amsterdam $\left(0.185<R^{2}<0.243\right)$.

Table 3 shows the results for the different tests, expressed as ECx and NOEC values. In some cases, data were rather scattered and did not allow for a calculation of reliable ECx values. In other cases, ECx values were far outside the range of concentrations tested, or $95 \%$ confidence intervals were very wide. The most reliable $\mathrm{EC}_{50}$ values for the effect of carbendazim on bait-lamina consumption ranged between 2.0 and $56 \mathrm{~kg}$ a.i./ha, while NOEC values ranged from $<0.36$ to 


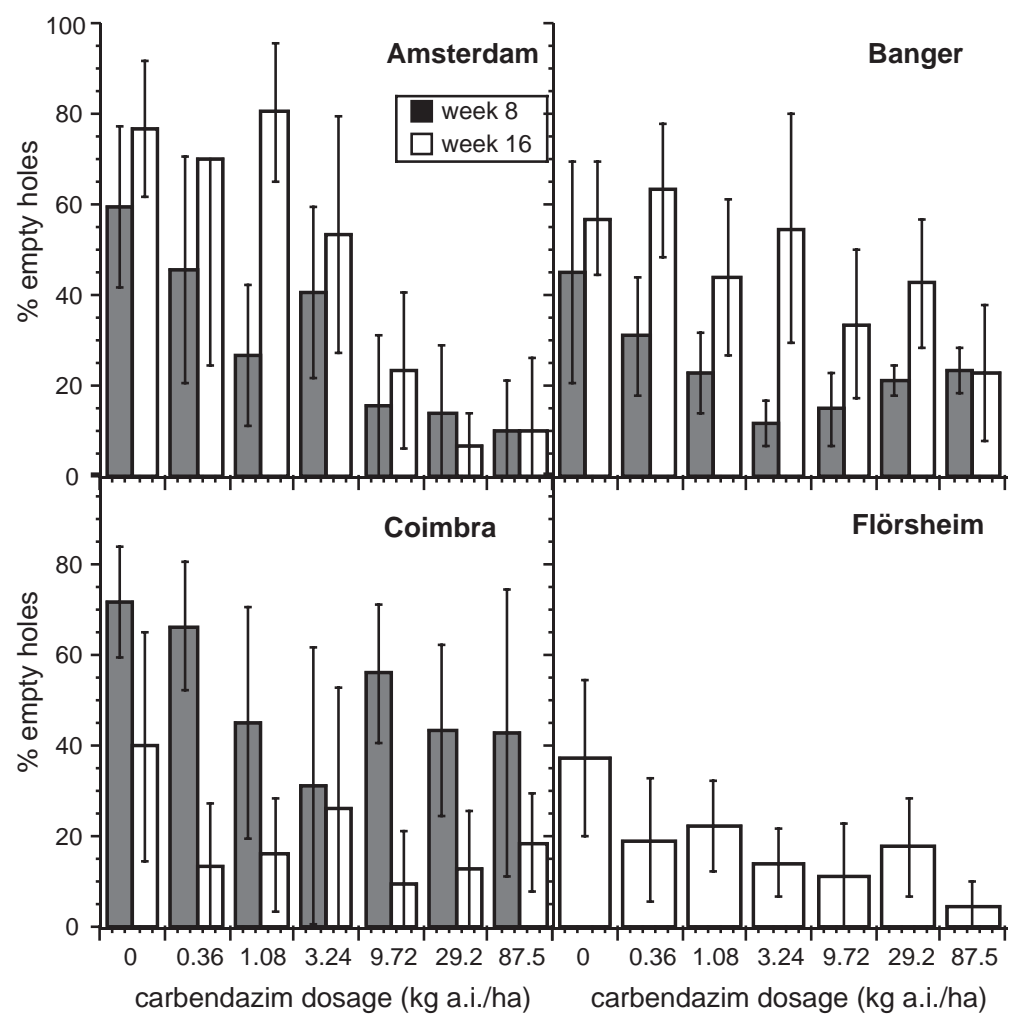

Figure 3. Effect of carbendazim on bait-lamina consumption, expressed as the mean number of open holes [\%] after 2 weeks of incubation ( $n=20 ; \pm \mathrm{SD}), 8$ (light shaded columns) and 16 weeks (dark shaded columns) after application in the TME ring test performed in Amsterdam, Bangor, Coimbra and Flörsheim.

$13 \mathrm{~kg}$ a.i./ha. From Table 3 it is also obvious that ECx and NOEC values generally are lower for the grassland soils than for the arable soil in Coimbra. Most $\mathrm{EC}_{50}$ values were not markedly different between the tests performed by one partner, but this may be partly due to the variation in these values as indicated by the large $95 \%$ confidence intervals.

\section{Correlation of bait-lamina feeding rate with soil invertebrate density}

Correlations between bait-lamina feeding rate (\% of empty holes after 14 days incubation of the bait-lamina sticks in the soil) and soil invertebrate density were determined for the following 17 cases: TME pre-test after 8 and after 16 weeks for partners Flörsheim, Amsterdam and Bangor, TME ring-test after 8 and 16 weeks for partner Amsterdam, Bangor and Coimbra, and for Flörsheim after 16 weeks, and field-validation study after 16 weeks for all partners. In 10 out 17 cases, there was a significant $(p<0.05)$ positive correlation between bait-lamina feeding rate and earthworm density (individuals $/ \mathrm{m}^{2}$ ), while in 12 out of 17 cases bait-lamina feeding rate was significantly correlated with earthworm biomass (g dry mass/ $\mathrm{m}^{2}$ ). Correlations were positive, with $R^{2}$ ranging between 0.133 and 0.734 in case of significant correlations $(p<0.05)$. This is illustrated for earthworm density in the Amsterdam TME ringtest and field-validation study at week 16 in Fig. 4. The TME pre-tests did never yield a significant correlation after 8 weeks, neither did the Coimbra TME ring-test and field-validation study after 16 weeks. In 6 out of 16 cases, bait-lamina consumption was significantly positively correlated with enchytraeid numbers $\left(p<0.05 ; R^{2}=0.191-\right.$ 0.582 ). Bait-lamina consumption was never correlated with the abundance of mites and only in 


\section{Förster et al.}

Table 3. NOEC values and $\mathrm{EC}_{10}$ and $\mathrm{EC}_{50}$ values (with $95 \%$ confidence intervals) in $\mathrm{kg}$ a.i./ha for the effect of carbendazim on baitlamina feeding activity at different sampling times in the TME pre-test, TME ring test and field-validation study performed at four different sites

\begin{tabular}{|c|c|c|c|c|c|c|c|c|c|c|}
\hline \multirow[b]{2}{*}{ Site } & \multirow[b]{2}{*}{ Test } & \multicolumn{3}{|l|}{ Week 4} & \multicolumn{3}{|l|}{ Week 8} & \multicolumn{3}{|c|}{ Week 16} \\
\hline & & NOEC & $\mathrm{EC}_{10}$ & $\mathrm{EC}_{50}$ & NOEC & $\mathrm{EC}_{10}$ & $\mathrm{EC}_{50}$ & NOEC & $\mathrm{EC}_{10}$ & $\mathrm{EC}_{50}$ \\
\hline \multirow[t]{3}{*}{ Amsterdam } & TME-pre & 2.16 & $\begin{array}{l}0.88 \\
(-)\end{array}$ & $\begin{array}{l}8.7 \\
(1.4-53)\end{array}$ & 2.16 & $\begin{array}{l}1.5 \\
(0.11-22)\end{array}$ & $\begin{array}{l}3.2 \\
(0.18-57)\end{array}$ & $>77.8$ & $\begin{array}{l}10 \\
(-)\end{array}$ & $\begin{array}{l}11 \\
(6.7-18)\end{array}$ \\
\hline & TME ring & & & & 0.36 & $\#$ & $\begin{array}{l}2.6 \\
(0.42-16)\end{array}$ & 1.08 & $\begin{array}{l}1.3 \\
(0.4-5.9)\end{array}$ & $\begin{array}{l}5.3 \\
(3.2-8.6)\end{array}$ \\
\hline & Field & & & & $<0.36$ & \# & \# & 9.72 & $\begin{array}{l}0.16 \\
(-)\end{array}$ & $\begin{array}{l}21 \\
(2.8-154)\end{array}$ \\
\hline \multirow[t]{3}{*}{ Bangor } & TME-pre & 2.16 & \# & $\begin{array}{l}2.6 \\
(-)\end{array}$ & 12.96 & \# & $\begin{array}{l}0.89 \\
(-)\end{array}$ & 0.36 & $\begin{array}{l}1.7 \\
(1.4-2.2)\end{array}$ & $\begin{array}{l}2 \\
(1.8-2.2)\end{array}$ \\
\hline & TME ring & & & & 0.36 & - & - & 29.2 & $\begin{array}{l}1.1 \\
(-)\end{array}$ & $\begin{array}{l}56 \\
(11-285)\end{array}$ \\
\hline & Field & & & & 3.24 & \# & $\begin{array}{l}71 \\
(-)\end{array}$ & 9.72 & $\begin{array}{l}0.56 \\
(-)\end{array}$ & $>87.5$ \\
\hline \multirow[t]{3}{*}{ Coimbra } & TME-pre & $>77.8$ & $\begin{array}{l}5.8 \\
(-)\end{array}$ & $\begin{array}{l}55 \\
(2.8-1069)\end{array}$ & $>77.8$ & $\begin{array}{l}5.9 \\
(-)\end{array}$ & $>77.8$ & $>77.8$ & $\begin{array}{l}68 \\
(46-102)\end{array}$ & $\begin{array}{l}75 \\
(-)\end{array}$ \\
\hline & TME ring & & & & 0.36 & - & \# & $<0.36$ & - & - \\
\hline & Field & & & & $>87.5$ & $>87.5$ & $>87.5$ & 9.72 & $>87.5$ & $>87.5$ \\
\hline \multirow[t]{3}{*}{ Flörsheim } & TME-pre & 13.0 & \# & $\begin{array}{l}1.4 \\
(-)\end{array}$ & 13.0 & \# & $\begin{array}{l}13.2 \\
(3.2-667)\end{array}$ & $<0.36$ & \# & $\begin{array}{l}3.6 \\
(0.42-31)\end{array}$ \\
\hline & TME ring & & & & & n.d. & n.d. & $<0.36$ & $\#$ & $\begin{array}{l}0.41 \\
(-)\end{array}$ \\
\hline & Field & & & & & n.d. & n.d. & $>87.5$ & $\begin{array}{l}0.51 \\
(-)\end{array}$ & $\begin{array}{l}9.8 \\
(0.7-137)\end{array}$ \\
\hline
\end{tabular}

- ECx could not be calculated (scattered data); \# ECx far below lowest dosage level; (-) very large 95\% confidence interval; n.d. = not determined.

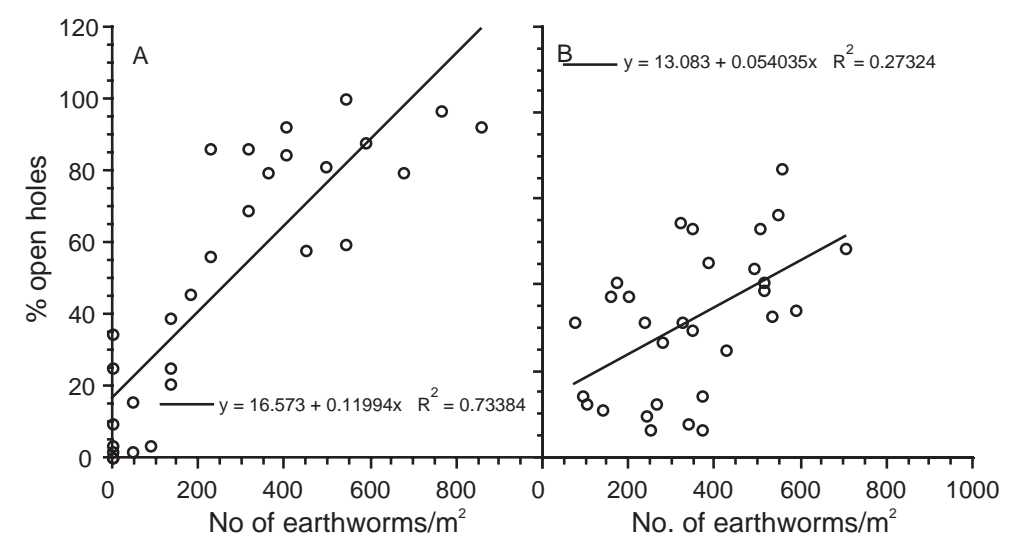

Figure 4. Correlation between bait-lamina feeding activity, expressed as the $\%$ of open holes after a 2 week incubation period, and the abundance of earthworms (numbers per $\mathrm{m}^{2}$ ) in the test soils. A (left). In the Amsterdam TME ring test. B (right). In the Amsterdam field-validation study. Both graphs show data for the sampling 16 weeks after treatment with carbendazim and include all treatment levels.

one out of seven cases it was significantly positively correlated with the number of Collembola
(Amsterdam TME ring-test; $p=0.031 ; \quad R^{2}=$ $0.161)$. 


\section{Discussion}

\section{Organic matter breakdown}

Although cellulose represents the major part of the decomposable plant residue material (Schick, 1999), pure cellulose does not occur in the environment and may therefore be criticized as too artificial. However, it has been used successfully to assess decomposition of $\mathrm{OM}$ in various studies (e.g. Schröder and Gewehr, 1977; Beyer et al., 1992; Schick, 1999; Kurka et al., 2000) and comparability with natural organic matter could be confirmed. For example, Bienkowski (1990) found identical decomposition rates of cellulose and barley straw when exposed in soil under the same moisture and temperature conditions in the laboratory. On the other hand, Sørensen (1983) reported that pure cellulose decomposed faster and was incorporated to a greater extent into soil microbial biomass than barley straw. According to Schick (1999), the cellulose decomposition test is appropriate to detect ecotoxicological effects on decomposition of OM in soil.

In studies described in the literature, usually cellulose material was exposed in gauze litter bags with small mesh sizes that excluded soil macro fauna, such as earthworms (e.g. Unger, 1960; Kurka et al., 2000). We placed cellulose paper directly in the soil or on the soil surface without any encasement. This allowed for direct contact with the soil and unlimited access for all soil organisms, thus mimicking the field situation of exposed OM. Moreover, placing the OM without litter bags in/ on the soil minimized mechanical disturbances which is of particular importance for the TMEs.

The weight loss of cellulose paper as a measurement endpoint for the decomposition of organic material in grassland TMEs was comparable to the field plots. This was true for cellulose paper inserted into the soil as well as for cellulose paper placed on the soil surface. The weight loss of inserted cellulose paper was higher in the TMEs than in the field, while the variability of the data was of similar magnitude in both exposure scenarios. Low soil moisture contents during summer may explain the reduced decomposition rate in the field, since the soil in the TMEs was maintained moist throughout the entire test period. The frequent dessication of the cellulose exposed on the soil surface, resulting in a reduced microbial and faunal feeding activity, is assumed to be the reason for the decreased decomposition rate compared to that of buried cellulose. An increased decomposition rate of cellulose paper when inserted into soil has also been described by Kurka et al. (2000). The relevance of soil moisture and exposure scenario for the decomposition process could also be demonstrated when assessing the weight loss of cellulose paper exposed to homogenised soil taken from the field of partner 1 (Flörsheim) and incubated for 6 weeks under laboratory conditions. In this experiment, the cellulose paper placed on the soil surface lost on average $23 \% \pm 2.8 \%$ of its initial weight if the test vessels were protected from desiccation by a cover, but only $2.2 \% \pm 1.1 \%$ if not covered and thus allowed to dry between the weekly irrigating. If inserted into the soil the degradation of cellulose paper was enhanced, resulting in an average weight loss of $48.8 \% \pm 15.4 \%$ and $19.7 \% \pm 6.9 \%$ of the initial weight in the covered and uncovered test vessels, respectively (data not shown). Schröder and Gewehr (1977) reported even higher decomposition rates with an average weight loss of $58 \%$ for cellulose paper exposed under laboratory conditions in soil for only 3 weeks. It is assumed that the use of cellulose paper discs caused the increased decomposition rate compared to the folded filter paper used in our test. The decomposition rate of inserted cellulose paper in grassland TMEs was within the range measured under laboratory conditions while the rate observed in the arable TMEs of Coimbra was much lower, possibly due to the low abundance of earthworms in the arable soil (Römbke et al., 2004).

Effects of carbendazim on soil micro-organisms in general can be assumed to be small although effects cannot be excluded, especially at high concentration rates (Krogh, 1991; WHO, 1993; Förster et al., 1996; Martikainen et al., 1998). The toxicity of the model chemical to enchytraeids and earthworms may have caused at least partly inhibition of cellulose degradation, as it is clearly indicated by the correlation factors $R^{2}=0.943$ and 0.886 for enchytraeids and earthworms, respectively. Nevertheless, the effects on decomposition were not predictable from the toxicity data on enchytraeids or earthworms since data were not correlated. The strong effects of the chemical in the 
arable TME of Coimbra may have been caused by the higher carbendazim amounts on the cellulose paper as compared to the amount of carbendazim in the cellulose paper of Flörsheim.

\section{Bait-lamina feeding rate}

Bait-lamina consumption showed fairly large variations in time within one and the same test, and also between different tests performed at the same site. Spatial heterogeneity of the soil fauna may have contributed to this finding (Irmler, 1998). Also variations in soil moisture content may have caused the variability of bait-lamina consumption (Federschmidt and Römbke, 1994; Larink, 1994b; Larink and Kratz, 1994; Müller et al., 1999; Paulus et al., 1999). Feeding activity was often higher in the TME ring-test compared to the TME pre-test. Since irrigation intensity was increased in the TME ring-test on the basis of the results of the pre-test, soil moisture levels generally were higher in the ring-test. By the end of the experiment, soil moisture content of Bangor TMEs was approximately $20-30 \%$ higher than in the corresponding field soils. This has undoubtedly affected the activity of soil organisms feeding on the bait-lamina substrate, as has been concluded by Larink (1994b) and several other authors. In field studies, also differences in temperature may have attributed to the variations in bait-lamina consumption observed.

Generally, bait-lamina consumption is assumed to be correlated with the activity of soil organisms. This was shown, for example, by Heisler and Brunotte (1998), Helling et al. (1998), and Kampmann (1994) for Collembola and enchy traeids. Heisler (1994), however, did not find a correlation between bait-lamina consumption and Collembola. In addition, Federschmidt and Römbke (1994) found indications for a contribution of earthworms and enchytraeids to baitlamina consumption. In the study reported here, bait-lamina consumption and earthworm density were correlated (Figure 4). Only in a few cases, a significant contribution of enchytraeids was found, and bait-lamina consumption appeared not to be affected by the abundance of soil arthropods.

Bait-lamina bait removal showed clear doseresponse relationships in all tests, except for the tests performed by Coimbra (arable soil). Since bait-lamina feeding was correlated with earthworm abundance, the lack of effects observed in Coimbra soil may be attributed to the very low number of these organisms in the arable soil. Striking was however, the large feeding activity observed; this could not be explained from the abundance or activity of soil invertebrates present in the arable soil of Coimbra. Maybe the loose structure of this soil, the fairly high temperatures in Portugal and the cultivation of Brassica rapa have stimulated substrate consumption. A reduction of bait-lamina consumption rates by soil compaction was reported by Heisler $(1994,1998)$ and Heisler and Brunotte (1998). It remains unclear, however, which organisms are responsible for the relatively high feeding rate in the arable soil, since only poor correlations were found with earthworm or enchytraeid densities. It also remains unclear whether this high feeding rate has to be attributed to excessive irrigation the TMEs and field plots. A high soil $\mathrm{pH}$ may also stimulate baitlamina consumption rates (Geissen and Brümmer, 1999). In this study, soil $\mathrm{pH}$ was highest in Coimbra, followed by Bangor, Flörsheim and Amsterdam soils, with average $\mathrm{pH}-\mathrm{KCl}$ ranging between $6.4-7.1,5.8-6.6,5.3-5.9$ and $4.8-5.1$, respectively.

Feeding behaviour, as quantified by the baitlamina test, showed good agreement between TMEs and field plots. Reduced bait removal was apparent with higher carbendazim treatment levels. Federschmidt and Römbke (1994) found no significant reduction of overall bait-lamina consumption by carbendazim dosages of 0.18 and $1.8 \mathrm{~kg}$ a.i./ha, but consumption activity was significantly reduced in the top layers of the treated soils compared to the deeper layers.

In this study, effects on bait-lamina feeding activity and cellulose paper decomposition were not correlated significantly although carbendazim inhibited both bait-lamina consumption and decomposition of cellulose paper. Ruf et al. (1997) found a dose-related reduction of bait-lamina consumption in Dimilin (diflubenzuron) treated soils, but no effects on the decomposition of beech leaves encased in litter bags were recorded. According to Ruf et al. (1997) the discrepancy of the two responses was attributed to the different spatial and temporal scales covered by the two methods. 


\section{Conclusions}

The assessment of decomposition as an integrative functional endpoint in TMEs is possible. Although it was validated only at the site of Flörsheim it seems that the pattern of cellulose paper decomposition in TMEs is comparable to cellulose paper decomposition under respective field conditions. Effects of carbendazim on decomposition were also comparable as it is indicated by similar $\mathrm{EC}_{50}$ values. Cellulose filter paper seems to be an appropriate material to assess $\mathrm{OM}$ decomposition whether inserted into the soil or placed on the soil surface. While the effects of the model chemical carbendazim on cellulose degradation in the grassland TMEs were comparable to the field, the reduced decomposition of cellulose at increasing carbendazim concentrations could neither be fully explained by soil fauna feeding activity assessed by the bait-lamina method and the abundance/biomass of the selected groups of the soil fauna (Koolhaas et al., 2004; Moser et al., 2004; Römbke et al., 2004) nor by microbial activity (Sousa et al., 2004). Thus, decomposition of OM should be included into the risk assessment as a separate endpoint that integrates over the various structural and functional endpoints involved in OM breakdown. The different response of the bait-lamina test and cellulose decomposition suggests that these two parameters are indicative of effects on different groups of soil organisms. As such, it might be advisable to use both methods next to each other.

\section{Acknowledgements}

This research was financially supported by the European Union (Project No. ENV4-CT97-0470).

\section{References}

Bengtsson, G., Berden, M. and Rundgren, S. (1988). Influence of soil animals and metals on decomposition processes: a microcosm experiment. J. Environ. Qual. 17, 113-9.

Beyer, L., Blume, H.-P., Friedrich, F. and Vogt, J. (1992). Der durchschnittliche, langfristige Abbau vergrabener Zellulose in typischen Acker- und Waldböden der Norddeutschen Tiefebene. Pedobiologia 36, 11-20.
Bienkowski, P. (1990). Cellulose decomposition as bioenergetic indicator of soil degradation. Pol. Ecol. Stud. 16, 235-44.

Bjørnlund, L., Ekelund, F., Christensen, S., Jacobsen, C.S., Krogh, P.H. and Johnsen, K. (2000). Interactions between saprotrophic fungi, bacteria and protozoa on decomposing wheat roots in soil influenced by the fungicide fenpropimorph $\left(\right.$ Corbel $\left.^{\circledR}\right)$ : a field study. Soil Biol. Biochem. 32, 967-75.

Cadisch, G. and Giller, K.E. (1997). Driven by Nature. Plant Litter Quality and Decomposition. CAB International, Wallingford, UK, 409 pp.

Chen, S.-K. and Edwards, C.A. (2001). A microcosm approach to assess the effects of fungicides on soil ecological processes and plant growth: comparisons of two soil types. Soil Biol. Biochem. 33, 1981-91.

Cortet, J. and Poinsot-Balaguer, N. (2000). Impact of phytopharmaceutical products on soil microarthropods in an irrigated maize field: the use of the litter bag method. Can. J. Soil Sci. 80, 237-49.

Eijsackers, H. and Zehnder, A.J.B. (1990). Litter decomposition: a Russian matriochka doll. Biogeochemistry 11, 153-74.

Federschmidt, A. and Römbke, J. (1994). Erfahrungen mit dem Köderstreifen-Test auf zwei fungizidbelasteten Standorten. Braunschw. Naturkdl. Schr. 4, 675-80.

Förster, B., Eder, M., Morgan, E. and Knacker, T. (1996). A microcosm study of the effects of chemical stress, earthworms and microorganisms and their interaction upon litter decomposition. Eur. J. Soil Biol. 32, 25-33.

Geissen, V. and Brümmer, G. (1999). Decomposition rates and feeding activities of soil fauna in deciduous forest soils in relation to soil chemical parameters following liming and fertilization. Biol. Fertil. Soils 29, 335-42.

Gillett, J.W. and Witt, J.M. (1980). Chemical evaluation: projected application of terrestrial microcosm technology. In J.P. Giesy Jr. (ed). Microcosms in Ecological Research, Technical Information Center US Department of Energy; Springfield, Virginia, USA, pp. 1008-33.

Gulley, D.D., Boelter, A.M. and Bergman, H.L. (1991). TOXSTAT. (Release 3.3. ed). Laramie: Fish Physiology and Toxicology Laboratory, Department of Zoology and Physiology, University of Wyoming.

Haanstra, L., Doelman, P. and Oude Voshaar, J.H. (1985). The use of sigmoidal dose response curves in soil ecotoxicological research. Plant Soil 84, 293-7.

Heisler, C. (1994). Vergleich zwischen der biotischen Aktivität nach Von Törne und der Collembolen-Zahl verdichteter Ackerböden. Zool. Beitr. N.F. 35, 19-26.

Heisler, C. (1998). Beeinflussung der biologischen Aktivität und Fruchtfolge. Agribiol. Res. 51, 289-97.

Heisler, C. and Brunotte, J. (1998). Beurteilung der Bodenbearbeitung mit Pflug und der konservierenden Bodenbearbeitung hinsichtlich der biologischen Aktivität mittels des Köderstreifen-Tests nach Von Törne sowie der Populationsdichten von Collembolen und Raubmilben. Landbauforschung Völkenrode 2, 78-85.

Helling, B., Pfeiff, G. and Larink, O. (1998). A comparison of feeding activity of collembolan and enchytraeid in laboratory studies using the bait-lamina test. Appl. Soil Ecol. 7, 207-12. 
Irmler, U. (1998). Spatial heterogeneity of biotic activity in the soil of a beech wood and consequences for the application of the bait-lamina-test. Pedobiologia 42, 102-8.

Kampmann, T. (1994). Entwicklung eines standardisierten Labortests mit Köderstreifen für ökotoxikologische Prüfungen: Erste Vorversuche. Braunschw. Naturkdl. Schr. 4, 681-6.

Knacker, T., Van Gestel, C.A.M., Jones, S.E., Soares, A.M.V.M., Schallnaß, H.-J., Förster, B. and Edwards, C.A. (2004). Ring-testing and field-validation of a Terrestrial Model Ecosystem (TME) - an instrument for testing potentially harmful substances: conceptual approach and study design. Ecotoxicology 13, 9-27.

Koolhaas, J.E., Van Gestel, C.A.M., Römbke, J., Soares, A.M.V.M. and Jones, S.E. (2004). Ring-testing and fieldvalidation of a Terrestrial Model Ecosystem (TME) - an instrument for testing potentially harmful substances: effects of the model chemical carbendazim on soil microarthropod communities. Ecotoxicology 13, 75-88.

Kratz, W. (1998). The bait-lamina test - general aspects, applications and perspectives. Environ. Sci. Pollut. Res. 5, 94-6.

Krogh, P.H. (1991). Perturbation of the soil micro arthropod community with the pesticides benomyl and isofenphos. Pedobiologia 35, 71-88.

Kula, C. and Römbke, J. (1998). Evaluation of soil ecotoxicity tests with functional endpoints for the risk assessment of plant protection products - state-of-the-art. Environ. Sci. Pollut. Res. 5, 55-60.

Kurka, A.-M., Starr, M., Heikinheimo, M. and Salkinoja-Salonen, M. (2000). Decomposition of cellulose strips in relation to climate, litterfall nitrogen, phosphorus and $\mathrm{C} / \mathrm{N}$ ratio in natural boreal forests. Plant and Soil 219, 91-101.

Kurka, A.-M., Starr, M., Karsisto, M. and Salkinoja-Salonen, M. (2001). Relationship between decomposition of cellulose strips and chemical properties of humus layer in natural boreal forests. Plant and Soil 229, 137-46.

Larink, O. (1994a). Der Köderstreifen-Test in der Pflanzenschutzmittel-Prüfung. Braunschw. naturkdl. Schr. 4, 671-4.

Larink, O. (1994b). Bait lamina as a tool for testing feeding activity of animals in contaminated soils. In Donker, M.H, Eijsackers, H. and Heimbach, F. (eds). Ecotoxicology of Soil Organisms, Boca Raton, Florida, USA: Lewis Publishers, pp. 339-45.

Larink, O. and Kratz, W. (1994). Köderstreifen-workshop in Braunschweig - ein Resümee. Braunsch. naturkdl. Schr. 4, 647-51.

Martikainen, E., Haimi, J. and Ahtiainen, J. (1998). Effects of dimethoate and benomyl on soil organisms and soil processes - a microcosm study. Appl. Soil Ecol. 9, 381-7.

Moser, T., van Gestel, C.A.M., Jones, S.E., Koolhaas, J.E., Rodriguez, J.M.L. and Römbke, J. (2004a). Ring-testing and field-validation of a Terrestrial Model Ecosystem (TME) - an instrument for testing potentially harmful substances: effects of carbendazim on enchytraeids. Ecotoxicology 13, 89-103.

Moser, T., Schallnaß, H.-J., Jones, S.E., Van Gestel, C.A.M., Koolhaas, J.E., Rodrigues, J.M.L. and Römbke, J. (2004b). Ring-testing and field-validation of a Terrestrial Model Ecosystem (TME) - an instrument for testing potentially harmful substances: effects of carbendazim on nematodes. Ecotoxicology 13, 61-74.

Römbke, J., van Gestel, C.A.M., Jones, S.E., Koolhaas, J.E., Rodrigues, J.M.L. and Moser T. (2004b). Ring-testing and field-validation of a Terrestrial Model Ecosystem (TME) an instrument for testing potentially harmful substances: effects of carbendazim on earthworms. Ecotoxicology 13, $105-118$.

Müller, G., Broll, G. and Tarnocai, C. (1999). Biological activity as influenced by microtopography in a cryosolic soil, Baffin Island, Canada. Permafrost Periglacial Processes 10, 279-88.

Paulus, R., Römbke, J. and Beck, L. (1999). A comparison of the litterbag-, minicontainer- and bait-lamina-methods in an ecotoxicological field experiment with diflubenzuron and btk. Pedobiologia 43, 120-33.

Ruf, A., Römbke, J., Paulus, R. and Beck, L. (1997). Die Wirkung von Dimilin auf Individuen und Populationen von Bodentieren und die biologische Aktivität des Bodens eines Laubwaldes. Mitt. Dtsch. Ges. Allg. Angew. Ent. 11, 211-5.

Salminen, J. and Haimi, J. (1997). Effects of pentachlorophenol on soil organisms and decomposition in forest soil. J. Appl. Ecol. 34, 101-10.

Schick, H. (1999). Der Celluloseabbautest - Ein funktionales Testverfahren zur Beurteilung der Lebensraumfunktion des Bodens für Bodenorganismen. Braunschw. naturkdl. Schr. 5, 925-34.

Schönborn, W. and Dumpert, K. (1990). Effects of pentachloro phenol and 2,4,5-trichlorophenoxyacetic acid on the microflora of the soil in a beech wood. Biol. Fertil. Soils 9 , 292-300.

Schröder, D. and Gewehr, H. (1977). Stroh- und Zelluloseabbau in verschiedenen Bodentypen. Z. Pflanzenernähr. Bodenk. 140, 273-84.

Sheppard, S.C. (1997). Toxicity testing using microcosms. In: Tarradellas, J., Bitton, G. and Rossel, D. (eds). Soil Ecotoxicology, Lewis Publishers, Boca Raton, pp. 345-73.

Sokal, R.R. and Rohlf, F.J. (1969). Biometry. San Francisco: W.H. Freeman.

Sorensen, L.H. (1983). Size and persistence of the microbial biomass formed during the humification of glucose, hemicellulose, cellulose, and straw in soils containing different amounts of clay. Plant and Soil 75, 121-30.

Sousa, J.P., Rodrigues, J.M.L., Loureiro, S., Soares, A.M.V.M., Jones, S.E., Förster, B. and van Gestel, C.A.M. (2004). Ring-testing and field-validation of a Terrestrial Model Ecosystem (TME) - an instrument for testing potentially harmful substances: effects of carbendazim on soil microbial parameters. Ecotoxicology 13, 43-60.

Sowerby, A., Blum, H., Gray, T. and Ball, A. (2000). The decomposition of Lolium perenne in soils exposed to elevated $\mathrm{CO}_{2}$ : comparisons of mass loss of litter with soil respiration and soil microbial biomass. Soil Biol. Biochem. 32, 1359-66.

Swift, M.J., Heal, O.W. and Anderson, J.M. (1979). Decomposition in Terrestrial Ecosystems. Studies in Ecology, Volume 5. Blackwell Scientific Publications, Oxford, London, Edinburgh, Melbourne, $372 \mathrm{pp}$.

Unger, H. (1960). Der Zellulosetest, eine Methode zur Ermittlung der zellulolytischen Aktivität des Bodens in Feld- 
versuchen. Zeitschr. Pflanzenernähr. Düng. Bodenkunde 91, 44-52.

Van Wensem, J. (1989). A terrestrial micro-ecosystem for measuring effects of pollutants on isopod-mediated litter decomposition. Hydrobiologia 188/189, 507-16.

Velthorst, E.J. (1993). Manual for chemical water analysis. Department of Soil Science and Geology, Agricultural University, Wageningen, The Netherlands.

Vink, K. and Van Straalen, N.M. (1999). Effects of benomyl and diazinon on isopod-mediated leaf litter decomposition in microcosms. Pedobiologia 43, 345-59.
Von Törne, E. (1990a). Assessing feeding activities of soil-living animals. I. Bait-lamina-test. Pedobiologia 34, 89-101.

Von Törne, E. (1990b). Schätzungen von Fressaktivitäten bodenlebender Tiere. II. Mini-Köder-Tests. Pedobiologia 34, 269-79.

WHO (1993). Carbendazim. Environmental Health Criteria 149. Published under the joint sponsorship of the United Nations Environment Programme, the International Labour Organisation, and the World Health Organisation, Geneva, Switzerland, pp. 1-125. 